\title{
Digital Customer Service Trends: Challenges and Opportunities
}

\author{
Michal Dostál \\ Technical University of Liberec, Faculty of Economics, Department of Informatics, \\ Studentská 1402/2, 46117 Liberec, Czech Republic \\ e-mail: michal.dostal1@tul.cz
}

\begin{abstract}
Customer service is an essential part of many companies and their product and service portfolio. In the current times, customer service has shifted more towards its digital forms. In previous research four digital customer service trends have been identified: virtual assistants, customer service personalization, mobile technologies, and opinion mining. This article aims to compare these findings with reality by employing a focus group discussion with professionals and point out the opportunities and challenges that the companies implementing these trends are faced with. The results show that the findings correspond with academic literature.
\end{abstract}

\section{Keywords}

Customer service; Virtual assistant; Personalization; Mobile technologies; Opinion mining.

\section{Introduction}

Due to the global pandemic, the digital form of customer service has become more important and is widely used. Even the companies that did not use the digital services available to connect with customers have become savvier in this matter. They must adapt to current customer needs and standards, which are rapidly changing. Based on the literature research that the author of this article has conducted to map current digital trends in customer service, four areas of interest were selected. These areas in digital customer service are virtual assistants, customer service personalization, mobile technologies, and opinion mining (also called sentiment analysis).

This article focuses on synthesizing literature findings and findings from focus group discussion focused on the four digital customer service trends listed above. The first section describes used research methods, describing the approach to focus group discussion. In the main section of this article the main results of this research are presented.

\section{$1 \quad$ Methods of Research}

Based on author's previous research, where he reviewed current digital trends from different perspectives, the trends are now analyzed to point out the challenges and opportunities. To achieve this, the current statistics collected from current literature on this topic and from relevant data sources were synthesized. In order to confirm the results from the literature research, a focus group to gather qualitative data on this matter was created. The focus group comprised 15 professionals in the field of customer service. The participants were employees of companies local to the Czech Republic; however, some also operated on the international market or were part of international concern. 
The main topic of the focus group was the challenges and opportunities in digital customer service, specifically in the four areas of current trends. Following are the leading ten questions that the moderator asked during the discussion:

1. How do you perceive the usage of virtual assistants (or chatbots) in your company?

2. What are the main drawbacks of using virtual assistants?

3. Where do you see the opportunities for virtual assistants?

4. What forms of personalization of your customer service do you use?

5. From the service provider's point, where do you see drawbacks of using customer service personalization techniques?

6. In which directions do you see opportunities in customer service personalization?

7. How do you use mobile technologies in your services for customers?

8. What drawbacks and opportunities do you see in implementing mobile solutions in your customer service?

9. What is your experience with opinion mining techniques?

10. Where do you see opportunities for such technology? What are the drawbacks?

Write-up of notes taken during the focus group interview was repeatedly discussed afterward with the participants to ensure no important information was left out.

\section{$2 \quad$ Results and Discussion}

The following chapter discusses the results obtained during focus group discussion and compares them with academic literature findings.

\subsection{Virtual Assistant Technologies}

Into this category, both text-based and speech-based virtual assistants are included. A textbased virtual assistant can be a chatbot or a dialogue system. A speech-based assistant can be a virtual personal assistant (e.g., Siri, Alexa) or intelligent/smart agent [1]. According to Eurostat [2], only $2 \%$ of European companies use a chatbot in a use case, where the chatbot communicates with customers. The top three countries that use this technology the most are Denmark with 5\% of its companies, Spain and France with 3\%. The statistic is concerned with enterprises with more than ten employees.

Customer services supported by artificial intelligence are generally more accepted among customers with prior AI knowledge and who are not hesitant to share personal information [3]. Dubiel et al. [4] investigated the usage of virtual agents (VA), and the results show the following:

- Users use the VA technology mostly at home or in a car during driving.

- Both frequent users and infrequent users are concerned on a similar level about the privacy aspects of using such technology; however, the frequent users are more comfortable using VA in front of family members.

- Most of the users use VA for fact-checking, updates on weather, and playing music.

- Users are most concerned about the VA misunderstanding them or struggling to correctly recognize speech with an accent. 
Research by Tulshan and Dhage [5] shows that among the four most used virtual assistants (specifically voice assistants: Google Assistant, Siri, Cortana, and Alexa), the Google Assistant has the best performance in voice-based recognition and human free interaction; while the Siri assistant found in Apple devices is on the second place. Their results show that all four assistants could answer up to $17.35 \%$ of daily questions; however, the Google Assistant was found to be the most efficient with 59.80\%. According to [5], the main challenge for voice recognition technologies is that the voices of people vary, and they speak in different ways. This also corresponds with the results of [4], specifically, that people are concerned the most with VA technology not understanding them correctly.

The first three questions laid out in the Methods of Research section were thematically connected with the topic of this section. The discussion showed that the perception of virtual assistant technology in enterprises is overall positive. The focus group participants pointed out that employing chatbot solutions in their customer service increased the quality and availability of their service, which led to higher customer satisfaction. This very well corresponds with a statistic from [6] showing that $69 \%$ of customers prefer chatbots because they can provide quick replies to simple questions. According to [7], 56\% of customers prefer to message a business rather than make a phone call to customer service. Based on the feedback the focus group participants received from their customers, it is evident they are more inclined to use the chatbot technology when their inquiry or request is of a simple kind (e.g., inquiry about the order status or a software feature).

When discussing the main drawbacks of implementing the VA technology in the participant's companies, they pointed out some interesting remarks. The participants collectively agreed that the main drawback of implantation chatbot technology in their company was that it was very time-consuming. The process comprises, e.g., the preparation (initial project planning, selecting the suitable supplier of the technology, carefully selecting the use cases), implementation, and continuous adjustments based on feedback. Few of the participants also pointed out that the implementation costs are quite high.

The question regarding what the participants perceive as opportunities in using VA brought out interesting points and subsequent discussion. One of the discussed topics was the payment process through a virtual assistant. Only two of the professionals in the focus group had direct experience with implementing a payment feature into their VA. The conversation showed an interesting and promising feature for companies whose business model allows payment through VA. Another great opportunity, as perceived by the focus group participants, is the ability to automate a large number of repetitive tasks and, in the case of chatbots, use some rich formats as videos and pictures to support the communication.

\subsection{Customer Service Personalization}

According to [8], more than $50 \%$ of customers are willing to share the information about the product they like to get personalized discounts, and $83 \%$ of customers are willing to share their data to create a more personalized service for them. The core of customer service personalization is gathering data about the customers and creating a so-called user model. The services and contents are tailored to specific users and customers.

Personalization of customer service is a powerful tool for building long-term rapport and relationships with a company's customers [9]. It greatly impacts the quality of the companycustomer relationship and how the customer perceives the company. Therefore, customers are more likely to shop at companies that provide personalized recommendations and a more personal shopping experience [8]. 
Discussion of this topic in the focus group resulted in some interesting remarks. The participant agreed that as people are more open to new technologies, they are also willing to share their data and information about their buying habits. Therefore, it is quite easy to implement personalized service practices. As the difficulty of implementation is quite low, they identified this as the main opportunity from the customer's point of view. From the company's point of view, the main opportunity lies in developing useful skills in market and customer research and knowledge discovery in the user data.

The participants of the focus group also discussed some drawbacks and challenges that their companies are faced with when implementing and using service personalization. According to the majority of the participants, the most challenging aspect is security and data handling. It is very important to keep user and customer data safe and eliminate all security risks resulting in data leakage or, worse, publication of customer data on malicious websites and databases. Few participants also noted that many of their customers are not willing to share their data. The discussion showed that this might be age-related, as the younger age groups are more susceptible to data collection and consequent tailored services. The majority of customers of the few participants are customers of higher age - as this is their target group of customers.

\subsection{Mobile Technologies}

There are several tools and methods that companies can use in order to upgrade and modernize their customer service. One of them is to employ mobile technologies in their processes. It can be as simple as creating a mobile-friendly layout or version of the company website or e-shop. These steps radically upgrade the accessibility of services to the target customers.

In current times the mobile devices are a vital part of life for many people. It is an instrument for connecting them with their friends. Mobile devices provide people with entertainment and a sense of community through social media apps. In the last years, mobile devices also gained a very important role in the business environment, and therefore it becomes vital in the work environment. Many businesses and companies took advantage of that and customized their business model to accommodate the modern requirements of their customers.

The focus group participants seemed to have discussed this topic the most, as there are numerous ways to take advantage of mobile technologies available to us. They were asked about the ways their businesses and companies used mobile technologies. Tab. 1: shows the main areas of use cases where the mobile technologies are used in customer services the participants offer.

Tab. 1: Areas of use cases of mobile technologies

\begin{tabular}{|l|l|}
\hline \multicolumn{1}{|c|}{ Area of use cases } & \multicolumn{1}{c|}{ Description } \\
\hline Product marketing & $\begin{array}{l}\text { Use of product catalogs in the form of mobile apps; ability to view and } \\
\text { add product reviews }\end{array}$ \\
\hline Advertisement & Use of QR codes in promotional materials (both in print and online) \\
\hline Customer support & $\begin{array}{l}\text { Use of mobile application or mobile web page to connect with customer } \\
\text { support department, possible usage of chatbot technology. }\end{array}$ \\
\hline Sales & $\begin{array}{l}\text { Product catalogs in mobile apps or web pages with embedded e- } \\
\text { commerce capabilities. Mobile applications for discounts. }\end{array}$ \\
\hline
\end{tabular}

Source: Own 
The discussion led to a collective agreement that implementing mobile technologies as an upgrade to customer service is the easiest in terms of solutions available to companies. The participants agreed that the basic usage of mobile technologies is the development of web pages that are compatible with mobile devices (meaning they are optimized for viewing and browsing on small devices) and touch devices such as tablets or laptops with touch displays.

More than half of the focus group participants stated that they use or plan on implementing the QR code technology. According to them and the literature, e.g., [10], this technology is quite popular among their customers. In order to be able to use the QR codes, the customers only need to have either a special application installed on their mobile device or if they have a recent model of mobile devices, they do not have to install any application as the ability to read QR codes is embedded the camera app. Eventually, the needed application may already be installed on their devices as it is quite a commonly used feature.

As one of the possible drawbacks of using QR codes, the participants identified the fear of customers regarding the security of the QR codes. It is important for the customer where the QR code is located. A statistic [11] regarding the place where the customers feel most secure scanning the QR codes showed that customers feel safe using this technology at retailers (such as supermarkets, shops) the most with $45.48 \%$. In the second place, there are bars and restaurants with $42.55 \%$. The rest of the places deemed as secure by the customers is shown in Fig. 1.

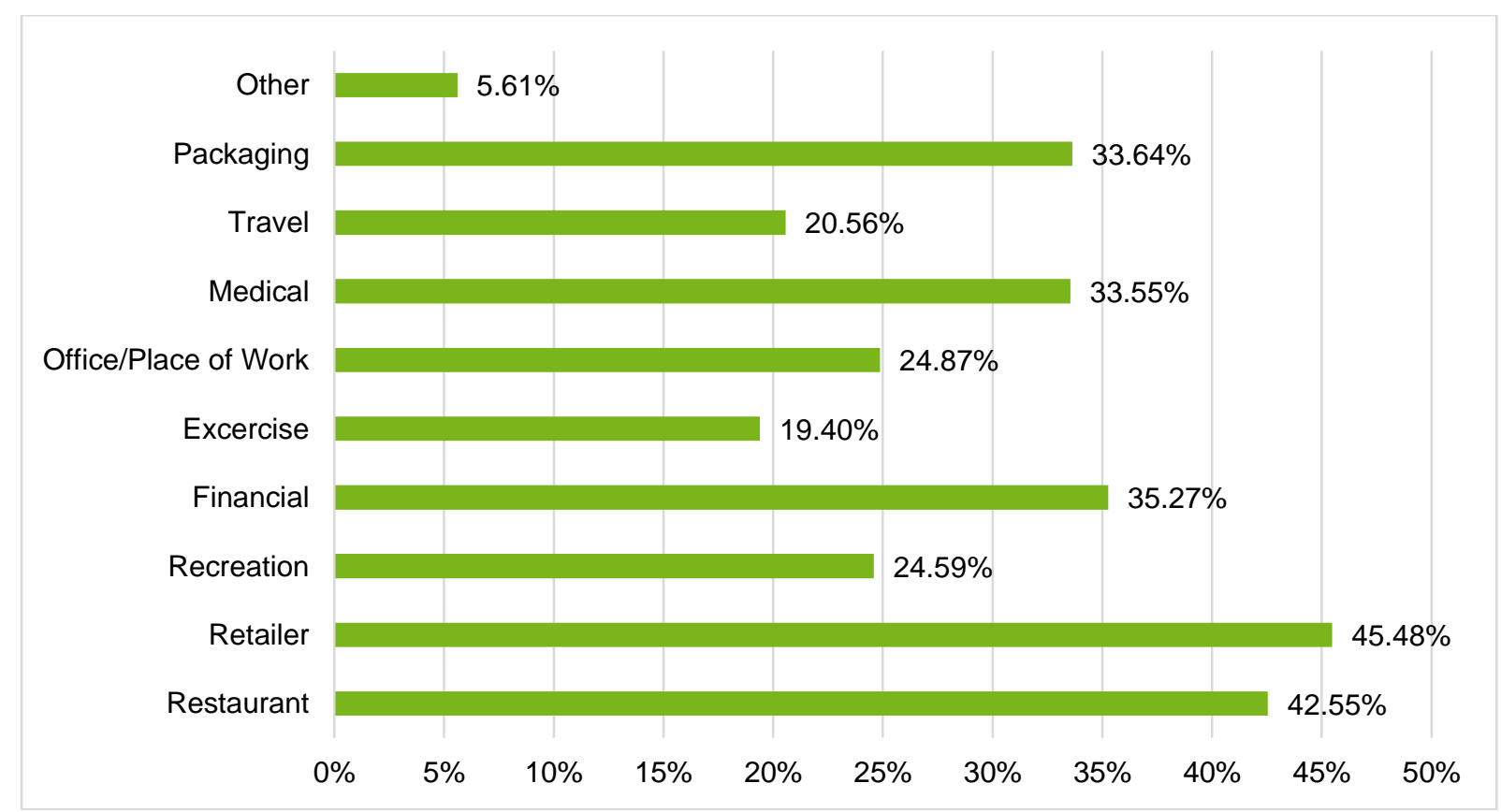

Source: Own adapted from [11]

Fig. 1: Secure locations for scanning $Q R$ codes

\subsection{Opinion Mining}

Among the focus group participants, opinion mining was extensively discussed; however, not many participants have their own experience with the technology. When the participants were asked question \#9 regarding their experience with opinion mining, their responses inclined more towards the theoretical level, meaning that many of them did some sort of research of this customer service tool; however, they did not decide to implement it yet. When asked about their reasoning behind this decision, a number of the participants agreed on the current inability of the systems to work with the Czech language, as some of the participants work mostly with Czech customers. 


\section{Are you thinking about implementing opinion}

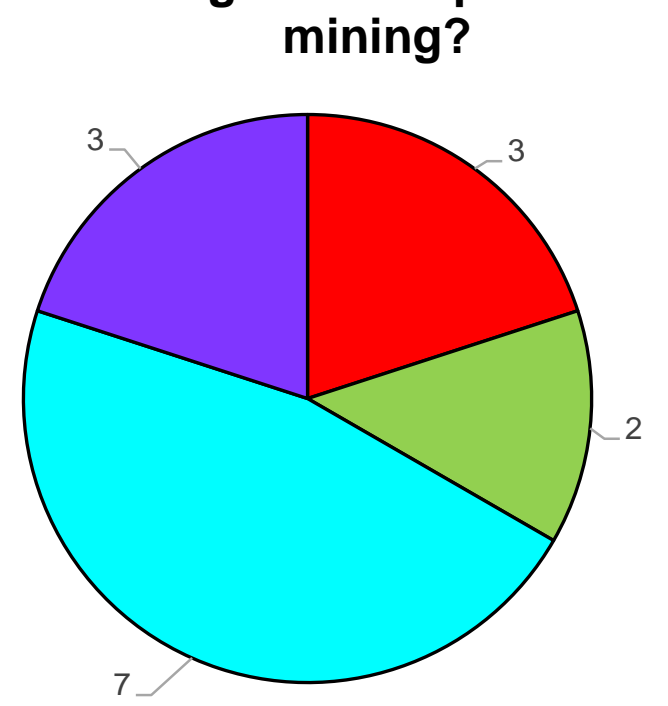

口Already implemented

口In the process

口Yes

$\square$ No

Source: Own

Fig. 2: Number of answers of focus group participants when discussing the intentions to implement opinion mining

One of the remarks recorded throughout the discussion was that smaller local companies do not find the customer opinion mining technology useful to them at this time. On the other hand, the participants from companies that are part of international concerns or have stakeholders from bigger firms stated that this part of customer service is of big interest for their future service improvement.

The participants were also asked what they perceive as opportunities and drawbacks of using the opinion mining technology. The biggest opportunity of employing opinion mining into the customer service process is to gain useful information about the customer's satisfaction with the product or service provided. This way, the company can adjust its customer service strategies to improve the rate of happy, loyal, and returning customers. Participants widely discussed the possible use cases they would see fit. Mentioned were product reviews from customers, real-time sentiment analysis of customers during calls or chats with customer support, post-call analysis of the transcript of customer-operator communication, analysis of the comment/discussion board on their e-shop product pages. This well corresponds with academic literature $[12,13]$.

There were three participants (see Fig. 2) whose firms and enterprises already use the opinion mining capabilities. They described their use cases and some of their best practices from implementing them. According to them, the biggest advantage in using such technology is in the amount of data about the satisfaction of their customers as they can quickly customize and alter their services to fit the needs of their customers. There were also two participants who were in the process of implementing the opinion mining technology. Seven participants were thinking about applying this technology, and three did not plan to implement opinion mining.

Many of the professionals participating in the focus group stated that the cost of implementation is one of the biggest drawbacks in adopting this technology in their businesses. In this sense, the implementation of opinion mining features is more interesting to companies that can use the potential to the fullest, generate some viable outcomes but mainly afford it in the long run. Many participants concluded that opinion mining is very interesting and, when used efficiently, a powerful tool. 


\section{Conclusion}

In this article the opportunities and challenges of current digital customer service trends identified in author's previous work were analyzed. A focus group was formed comprising several professionals who discussed those trends. The findings were compared with literature and corresponding statistics. Tab. 2 summarizes the main opportunities and challenges identified by the focus group participants, and therefore the results of this research.

Tab. 2: Summary of main opportunities and challenges when implementing digital customer service trends

\begin{tabular}{|l|l|l|}
\hline \multicolumn{1}{|c|}{ Trend } & \multicolumn{1}{c|}{ Opportunities } & \multicolumn{1}{c|}{ Challenges } \\
\hline Virtual Assistants & $\begin{array}{l}\text { Payment through VA. Automation } \\
\text { of repetitive tasks. }\end{array}$ & $\begin{array}{l}\text { Time-consuming implementation. } \\
\text { Implementation costs. }\end{array}$ \\
\hline Personalization & Knowledge discovery in user data. & $\begin{array}{l}\text { Security. Data handling. Consent for } \\
\text { data sharing. }\end{array}$ \\
\hline $\begin{array}{l}\text { Mobile } \\
\text { Technologies }\end{array}$ & QR codes. Mobile applications. & $\begin{array}{l}\text { Possible security issues (QR code } \\
\text { scams) }\end{array}$ \\
\hline Opinion Mining & Useful customer satisfaction data. & Cost of implementation. \\
\hline
\end{tabular}

Source: Own

\section{Acknowledgments}

This work was supported by the Student Grant Competition of the Technical University of Liberec under project No. SGS-2021-1014.

\section{Literature}

[1] GNEWUCH, U.; MORANA S.; MAEDCHE A.: Towards Designing Cooperative and Social Conversational Agents for Customer Service. In: Proceedings of the International Confernce on Information Systems 2017. Seoul, South Korea, 2017.

[2] EUROSTAT: ISOC_EB_AI dataset. [online]. 2021. Available from WWW: https://ec.europa.eu/eurostat/databrowser/product/view/ISOC_EB_AI?lang=en

[3] ISIDORE, R.; ARUN, J.: Are Indian Consumers Happy with Artificial Intelligence Enabled Personalized Customer Service. Academy of Marketing Studies Journal. 2021, Vol. 25, pp. 1-16. ISSN 10956298.

[4] DUBIEL, M.; HALVEY, M.; AZZOPARDI, L.: A Survey Investigating Usage of Virtual Personal Assistants. arXiv:1807.04606. [online]. 2018. Available from WWW: http://arxiv.org/abs/1807.04606

[5] TUlShAN, A.; DHAGE, N.: Survey on Virtual Assistant: Google Assistant, Siri, Cortana, Alexa. In: Thampi S.; Marques O.; Krishnan S.; Li K.; Ciuonzo D.; Kolekar M. (eds.), Advances in Signal Processing and Intelligent Recognition Systems. Singapore: Springer Singapore, 2019, pp. 190-201. ISBN 9789811357572. DOI: $10.1007 / 978-981-13-5758-9 \_17$

[6] EQUITY: Chatbot Report 2018: Global Trends and Analysis. [online]. 2018. Available from WWW: https://chatbotsmagazine.com/chatbot-report-2018-global-trends-andanalysis-4d8bbe4d924b 
[7] CHADHA, T.: 50+ Vital Chatbot Statistics for 2021 to Know Post Pandemic. [online]. 2021. Available from WWW: https://outgrow.co/blog/vital-chatbot-statistics/

[8] MORGAN, B.: 50 Stats Showing The Power Of Personalization. [online]. Available from WWW: https://www.forbes.com/sites/blakemorgan/2020/02/18/50-stats-showingthe-power-of-personalization/

[9] BANYTE, J.; GADEIKIENE, A.; RUTELIONE, A.; KAKNEVICIENE, I.: Expression of Personalization while Developing Long-Term Relationships with Service Customers. Engineering Economics. 2016, Vol. 27, Issue 4, pp. 462-471. ISSN 2029-5839. DOI: $\underline{10 / g k d c 2 m}$

[10] OCHOCKA, J.; Mobile Technologies in Logistic Customer Service as a Tool for Winning Customers' Satisfaction. Logforum. 2019, Vol. 15, Issue 3, pp. 403-411. ISSN 18952038, 1734459X. DOI: $\underline{10 / g k d c 2 j}$

[11] STATISTA: Secure locations for QR code scanning in the US and UK 2020. [online]. 2021. Available from WWW: https://www.statista.com/statistics/199325/qr-codescanners-by-gender/

[12] LI, P.; YAN, Y.; WANG, Ch.; REN, Z.; CONG, P.; WANG, H.; FENG, J.: Customer voice sensor: A comprehensive opinion mining system for call center conversation. In: Proceedings of 2016 IEEE International Conference on Cloud Computing and Big Data Analysis, ICCCBDA 2016, 2016, pp. 324-329. ISSN 9781509025930. DOI: $\underline{10.1109 / I C C C B D A .2016 .7529578 ~}$

[13] PAPPAS, D., ANDROUTSOPOULOS, I.; PAPAGEORGIOU, H.: Anger detection in call center dialogues. In: 2015 6th IEEE International Conference on Cognitive Infocommunications (CogInfoCom), 2015, pp. 139-144. DOI: 10/gigrb9

Ing. Michal Dostál 


\section{TRENDY DIGITÁLNÍCH ZÁKAZNICKÝCH SLUŽEB: VÝZVY A PŘÍLEŽITOSTI}

Služby zákazníkům jsou velmi důležitou součástí mnoha firem a jejich portfolia produktů a služeb. V současnosti se služby zákazníkům zaměřují především na jejich digitální podobu. V rámci provedeného předchozího výzkumu byly identifikovány čtyři současné trendy v digitálních službách zákazníkům: virtuální asistenti, personalizace služeb, mobilní technologie a opinion mining. Cílem tohoto článku je porovnat tato zjištění s realitou, a to pomocí diskuse $\mathrm{s}$ odborníky $\mathrm{v}$ rámci uspořádané focus group a též vyzdvihnout hlavní př́ležitosti a výzvy při implementaci těchto technologií. Výsledky korespondují se zjištěními v akademické literatuře.

\section{TRENDS IM DIGITALEN KUNDENSERVICE: HERAUSFORDERUNGEN UND MÖGLICHKEITEN}

Kundenservice ist ein sehr wichtiger Bestandteil vieler Unternehmen und ihres Produkt- und Dienstleistungsportfolios. In der aktuellen Zeit hat sich der Kundenservice mehr in Richtung seiner digitalen Formen verlagert. In meiner vorherigen Forschung wurden vier digitale Kundenservice-Trends identifiziert: virtuelle Assistenten, Kundenservice-Personalisierung, mobile Technologien und Meinungsforschung. Das Ziel dieses Papiers ist es, diese Ergebnisse mit der Realität zu vergleichen, indem eine Fokusgruppendiskussion mit Fachleuten durchgeführt wird, und zeigen die Chancen und Herausforderungen auf, mit denen die Unternehmen konfrontiert sind, die diese Trends umsetzen. Die Ergebnisse zeigen, dass die Ergebnisse mit der wissenschaftlichen Literatur übereinstimmen.

\section{TRENDY W CYFROWEJ OBSŁUDZE KLIENTA: WYZWANIA I SZANSE}

Obsługa klienta jest istotnym elementem wielu firm i ich portfela produktów i usług. W obecnych czasach obsługa klienta skupia się przede wszystkim na jej cyfrowej formie. Moje poprzednie badania zidentyfikowały cztery aktualne trendy w cyfrowej obsłudze klienta: wirtualni asystenci, personalizacja usług, technologie mobilne oraz eksploracja opinii. Niniejszy artykuł ma na celu porównanie tych ustaleń z rzeczywistością poprzez zastosowanie dyskusji $\mathrm{w}$ grupie fokusowej $\mathrm{z}$ udziałem specjalistów oraz wskazanie podstawowych szans i wyzwań, przed którymi stoją firmy wdrażające te technologie. Wnioski są zgodne z literaturą naukową. 